\title{
Disaster Mitigation for Palu City Residents in Dealing with Liquefaction Disasters in Accordance of Spatial Patterns of Palu City, Central Sulawesi Province, Indonesia.
}

\author{
Yudi Kuswandi ${ }^{1}$, Jossi Erwindi ${ }^{2}$, Moh. Sapari Dwi Hadian², Dicky Muslim² \\ ${ }^{I}$ Study Programs Of Regional Innovation Postgraduate School, Padjadjaran University, Indonesia. \\ ${ }^{2}$ Research Center for Environment, Engineering and Geological Disaster, Padjadjaran University, Indonesia.
}

\author{
* Corresponding author : bob.debuilders76@gmail.com \\ Tel.:+62-821-2150-4138 \\ Received: Oct 1, 2020; Accepted: Dec 08, 2020 \\ DOI 10.25299/jgeet.2020.5.4.5653
}

\begin{abstract}
Potential natural hazards in Palu City by paying attention to the real physical characteristics of Palu City are categorized as having a high level of disaster hazard. The geological character of both the geological structure and geological engineering in the Palu region shows the great potential for geological disaster hazards. On September 28, 2018, at 18: 02 CIT, an earthquake measuring 7.4 on the Richter scale, the quake's center located in $26 \mathrm{~km}$ of Donggala district and $80 \mathrm{~km}$ northwest of Palu City. By observing the epicenter's location and the depth of the hypocentral earthquake, it appears that this shallow earthquake occurred due to activity in the Palu Koro fault zone.

This fault is the most active in Sulawesi and is the most active in Indonesia with a movement of $7 \mathrm{~cm}$ per year. Liquidity disasters or ground liquefaction are also the effects of an earthquake. Shocks a massive quake causes the soil to melt this thing occurs when the saturated soil loses strength and stiffness due to stress. The Petobo area and the Balaroa - Perumnas are close to the Palu Koro active fault line and the land in the area is composed of soft material from the sedimentation process. This area is shallow groundwater with high soil permeability values, namely in the Petobo area and Perumnas - Balaroa.

The purpose of this study is to analyze the potential liquefaction disaster in Palu City and analyze the Palu City resident ability against Liquefaction Hazard Prone. This research uses a descriptive qualitative analysis method. Potential liquefaction disasters were analyzing qualitatively based on geological conditions and disaster locations. Disaster mitigation capabilities were analyzed qualitatively based on the Palu City Spatial Pattern. One of the hazards caused by an earthquake that has the potential to be a disaster in Palu City is liquefaction.

The ability of residents to mitigate liquefaction in Palu City is influenced by local wisdom which is reflected in ancient times when people lived in the highlands or hills. the concept of building structures, land use, and spatial planning patterns in Palu City which can reduce the threat of liquefaction.
\end{abstract}

Keywords: Disaster, Geology, Liquefaction, Spatial Pattern, Mitigation.

\section{Introduction}

\subsection{Sub Introduction}

Palu City Area is part of Sulawesi Island which becomes gather area of the three Plates are Indo-Aussie, Eurasia, and the Philippines that condition makes it very vulnerable to tectonic earthquakes. The Indo-Aussie Plate moves to the north around $50-70 \mathrm{~mm} /$ year and knocking down under the inner SumateraJava sea trough until western Timor Island in Nusa Tenggara Timur Bock., in (Pakpahan et al., 2015). At the same time, The Pacific Plate crashed into the north side of Irian Island and the islands north of Maluku at a speed of $120 \mathrm{~mm} /$ year, it is twice faster than in the western and southern Indonesian area Bock., in (Pakpahan et al., 2015) which causes the formation of active faults to include the Palu-Koro fault, the Matano fault connected to the sliding fault line, the Mendoke fault, and the Lewanopo fault.

The City of Palu has a high-level disaster risk because bypassed the active fault Palu Koro, Palu City is one of the cities with a high level of disaster hazard compared to other regions, because it is passed by an active Palu Koro fault, so it is prone to earthquakes and other associated disasters such as ground movements, tsunamis, and liquefaction. (BNPB, 2013)

The regional geology of Palu and the surrounding area are dominated by the quarter consisting of fluviatile and alluvium deposits. This natural condition has several bad potentials include liquefaction potential. Based on the Geological Map Review Sheet Palu, Sulawesi Scale 1: 250,000 RabSukamto, et $\mathrm{al}$, in (Widyaningrum, 2012) the investigation area consists of 2 (two) formations rocks, namely Alluvium and coastal deposits (Qap) and Molasa Celebes Serasin and Serasin (QTms) as shown in Figure 1. Base on the result of Technical Geological analysis, The City of Palu is divided into two technical geology units, namely the Alluvium and the coastal sedimentation units (Qap) and the Molasa Celebes Sarasin and Seracin Unit (QTms). The area formed by Alluvium deposits can be explained as the soil layer generally consists of sand in the upper part, silt in the middle, and clay in the lower part. (Marjiyono et al., 2013)

Palu City Spatial Plan 2010-2030 regulated in Palu City Regional Regulation No. 16 of 2011 is one of the operational guidelines for development in Palu City. As one of the guidelines in development, especially the physical development of urban space in Palu City, the Neighbourhood Association 
(RTRW) of Palu City must be able to become a tool of operation for directing and control the dynamic of physical development. The issue of global climate change is also felt in Palu City and characterized by an earthquake and causes various problems and disruptions to the city's system of activities, such as problems related to global climate disasters (floods, droughts, and other disasters) and disasters resulting from the earthquake, namely Liquefaction (pemerintah daerah, 2010).

The ancestors of the Palu community have recorded liquefaction events in local terms, which indicates that they have recognized them for a long time. The liquefaction is called 'Nalodo' which means sucked up by the mud. Nalodo (Liquefaction) is one of the disasters causing damage to infrastructure include the people's houses that's why knowledge about a disaster is important especially for disaster mitigation for further cases. (Balitbang PUPR, 2018)

This paper aims to analyze the potential for liquefaction disasters in Palu City and analyzing the disaster mitigation capacity of the peoples against liquefaction prone disasters in Palu City, Southeast Sulawesi Province.

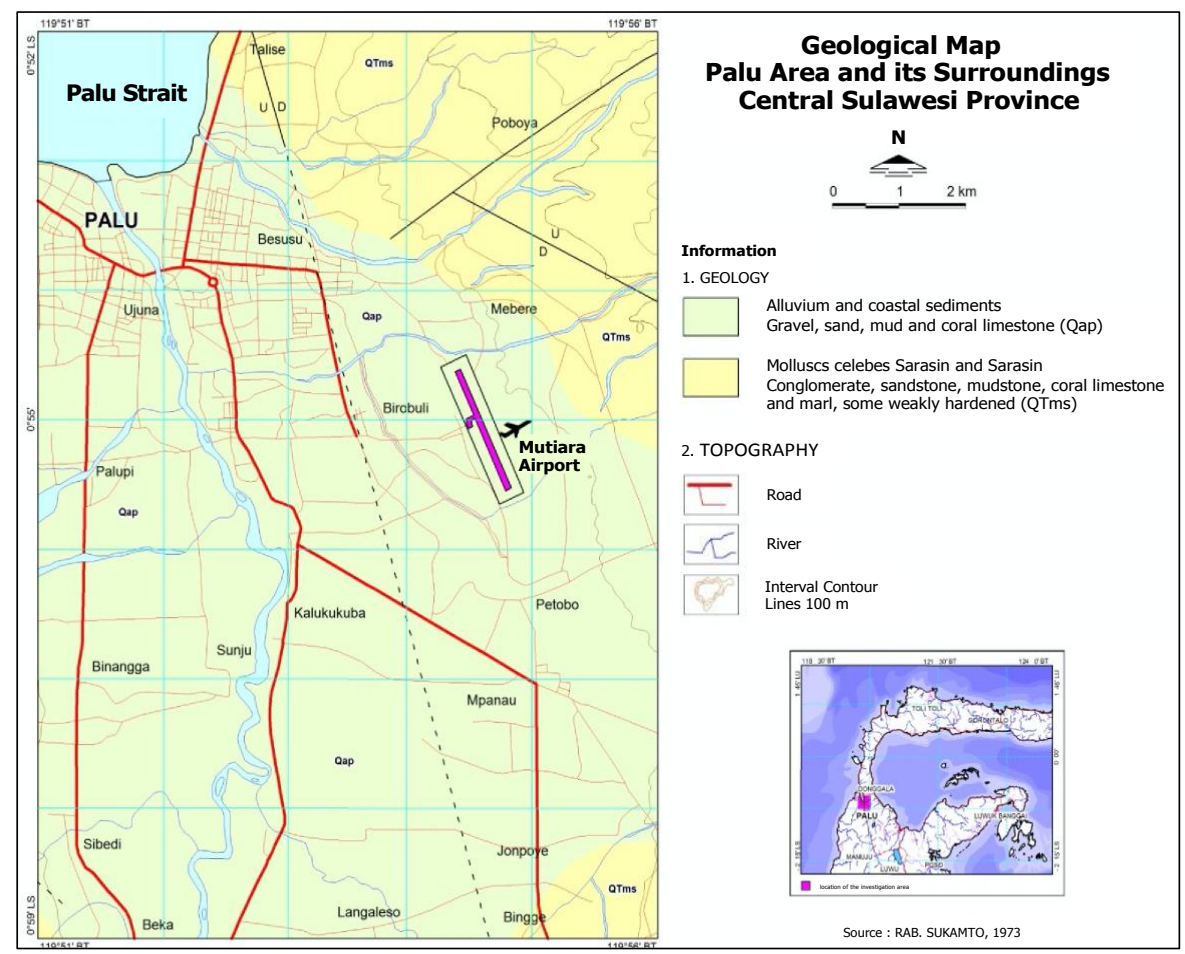

Fig 1. Geological Map of Palu and Surrounding Area

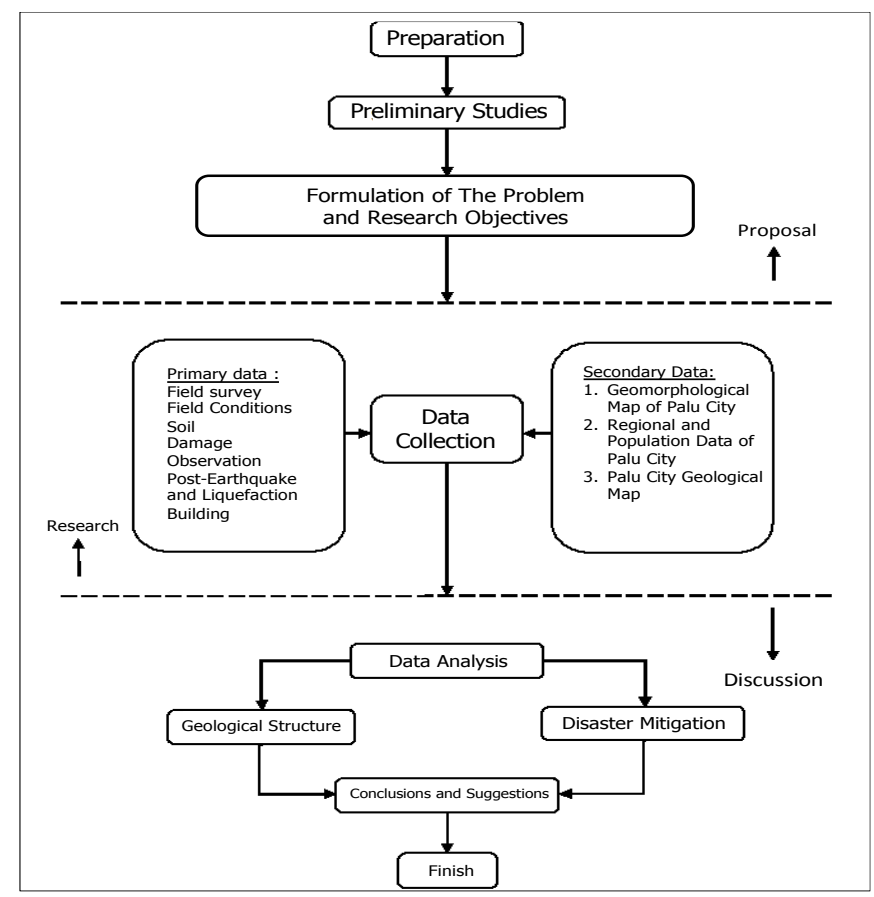

Fig 2. Flow Chart Methods

\section{Methods}

The methodology in this study uses a qualitative descriptive analysis method. This research is needed to raise and 
analyze a problem. The research is then described in an analysis to arrive at conclusions according to the original objectives. This type of qualitative descriptive research is a research method that utilizes qualitative data and describes a descriptive history. This type of qualitative descriptive research is often used to analyze social events, phenomena, or circumstances. This type of qualitative descriptive research is a combination of descriptive and qualitative research. This type of qualitative descriptive research displays the results of the data as they are without any manipulation or other treatment processes (Sugiyono, 2012:6). The potential for a liquefaction disaster is analyzed qualitatively based on the geological conditions and the location of the disaster. Disaster mitigation capabilities are analyzed qualitatively based on the Palu City Spatial Plan. Flow Chart Methods are shown in Figure 2.

\section{Results and Discussion}

Natural disaster-prone is a spatial designation that is part of a protected area that has certain characteristics both on land and in waters that often experience landslides, tidal waves/tsunamis, floods, volcanic eruptions, and earthquakes.

The function of determining natural disaster-prone areas is to determine a zone that cannot be used as a development location if the risk of disaster is high enough.

1) Serious prevention and response in natural disasters

2) Minimizing casualties due to natural disasters

3) Performance criteria for spaces prone to natural disasters include:

4) No development, if the risk of disaster is high enough

5) Serious implementation of prevention and response in natural disasters.

6) Minimizing the number of casualties due to natural disasters (Peraturan_Gubernur, 2019).

The potential danger of natural disasters in Palu City by paying attention to the natural physical characteristics of Palu
City is categorized as having a high level of disaster hazard. The geological character of both the geological structure and engineering geology in the Palu area shows great potential for geological disaster hazards. the character of the slopes and soil types, as well as rainfall, contributed to earthquakes, tsunami, liquefaction, floods, and landslides (Wicaksono, 2019).

In the Palu City area based on the results of the analysis identified the types of disasters that often occur and recur in Palu City are:

1) Earthquake - as an area through which the Palu Koro active fault passes, Palu City is an area that has high earthquake potential.

2) Tsunami - the effect from large force earthquake causes wave in the ocean, or due to landslides that occur in the sea. The City of Palu often experiences this Tsunami, in history recorded the greatest earthquake occurred in 1977 with a tsunami's height of up to 15 meters. The people of Palu City recognize this tsunami phenomenon as standing water.

3) Liquefaction - disasters of liquefaction are also the effects of an earthquake. Huge earthquake shocks cause the ground to melt. This occurs when saturated soil loses strength and stiffness due to stress. This area located close to the Palu Koro active fault line, and the land in the area is composed of soft material resulting from sedimentation. This area is shallow-groundwater with high soil permeability value beside in the Petobo area, there are many 'seepages' or groundwater seepages.

4) Flood - Palu City is passed by many rivers. The big one is called Palu River.

5) Landslide - Prone to landslides in areas with slope rates $>30 \%$, generally on medium to high altitudes (Rakhmawan et al., 2019).

The concept of the Palu City spatial pattern in terms of the landscape morphology of Palu City is divided into 3 area categories, namely lowlands, highlands, and mountains/hills as shown in Figure 3.

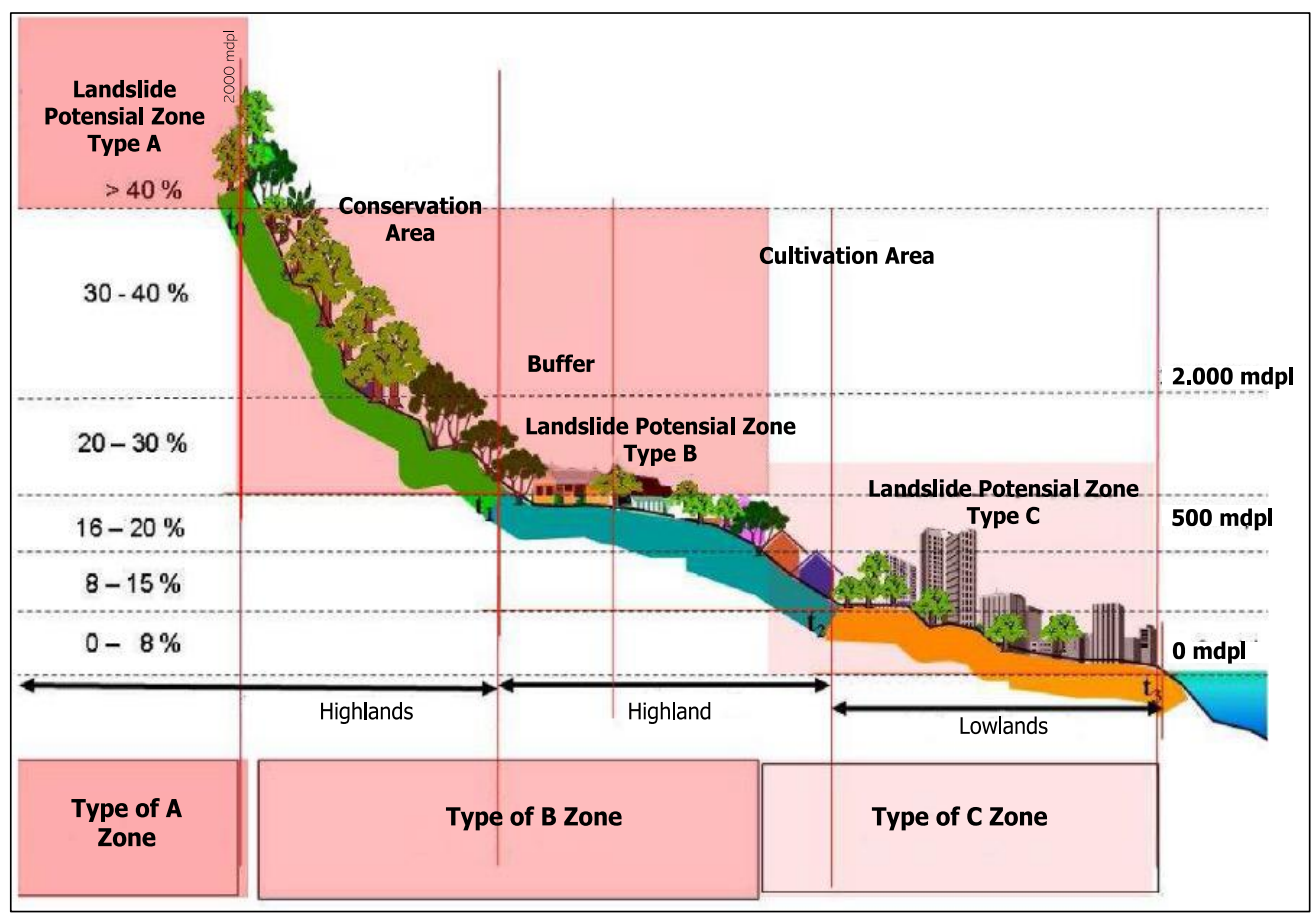

Fig 3. Concept of Spatial Pattern Based on Morphology in Palu City

The concept of Palu City spatial pattern is reviewed based on the morphological characteristics of the Palu City landscape, which is divided into three regional categories, namely lowlands, highlands, and mountains/hills.

1) Mountainous/hilly area Type A 
a. Areas with slope rates $>40 \%$ with elevations $>2000$ meters above sea level.

b. Directed to protected areas.

2) Plateau type $B$

a. Areas with slope rates of $20-40 \%$ with an altitude of 500-2000 meters above sea level.

b. Aimed at a buffer zone between a cultivation area and a protected area

3) Lowland Type $\mathrm{C}$

a. Areas with a slope of $0-20 \%$ with a height of $<500$ meters above sea level.

b. Directed to the area of cultivation (development of the City of Palu). Liquefaction Disaster in the City of Palu (pemerintah daerah, 2019a).

A qualitative approach to liquefaction potential applies to small scale or rock formations. The results of the qualitative method are a general description of the liquefaction potential. These results can be used as a basis for determining further qualitative investigation in more detail. The phenomenon of liquefaction is the impact of an earthquake in an area composed of loose sand layers with a shallow groundwater level $(<9.0 \mathrm{~m})$ and is influenced by the intensity and duration of the earthquake shock and the distance from the epicenter. According toYoud, in PuSGen, 2018), soil layers that are prone to liquefaction are in a relatively limited geological area. Liquefaction generally occurs in alluvial fan deposits, alluvial plains, beaches, former lakes, and estuaries.
The loose layer of fine sand beneath the ground surface in the coastal areas and plains of Palu City is very vulnerable to liquefaction. The phenomenon of soil mass flow and soil oscillation movement occurred in several regions.

The liquefaction that occurs in the hammer city occurs after an earthquake shaking, which causes the collapse of the land and buildings above it, the ground changes from initially solid and becomes liquid behavior and loses its strength. Liquefaction occurs in loose sandy soils and water-saturated medium which experience an increase in excess pore water pressure due to the blocking of the earthquake waves to the soil surface. Sand and silty sand are types of soil that are subject to liquefaction (Mina et al., 2018).

The loose layer of fine sand beneath the ground surface in the coastal areas and plains of Palu City is very vulnerable to liquefaction. The phenomenon of soil mass flow and soil oscillation movement occurred in several areas.

The location in the Palu City of the liquefaction disaster is a depressed area around a large old alluvial sphere, and also the event is followed by an alluvial fan with a relatively smaller size (flood cone) on high topography. The depressed territory is the area of sediment deposits that have the potential to become areas of floodplain and high sedimentation area. (Harun Mallisa et al., 2009).

The mechanism of liquefaction occurs in Palu City is shown in Figure 4 (BAPPENAS, 2019a).

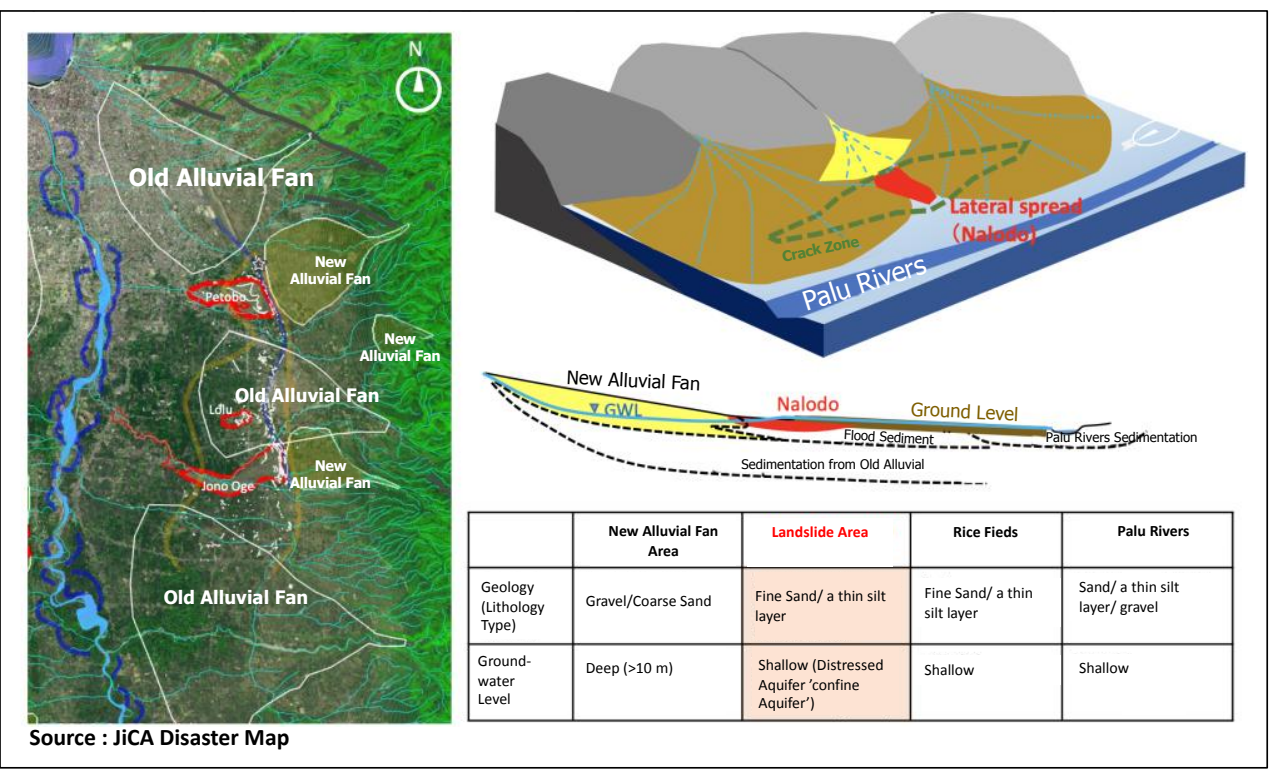

Fig 4. The mechanism for liquefaction (Nalodo) in Palu City.

The causes of the liquefaction disaster in Palu City are several things, namely:

1) The condition of sandy soils which are not tightly bound (loose) making it possible to melt

2) Shallow groundwater-surface < of 5 meters.

3) The tilt gradient corresponding to $\left(\geq 2^{\circ}\right)$

4) The condition of a hard rock layer as a hood.

A.The triggering factor of the liquefaction disaster in Palu City are:

1) The vibration from an earthquake.

2) There is an unusual pore pressure.

B. Areas that occur liquefaction in the city of Palu, namely: 1) In areas around active faults.
2) Active fault cliffs form alluvial fans.

3) In the flood sediment area at the end of the alluvial fan.

4) In the large alluvial fan boundary area.(BAPPENAS, 2019b).

Liquefaction is a unique phenomenon that soil material behaves more like a liquid than a solid so that it completely loses its durability SNI 8460: 2017 (Badan Standarisasi nasional, 2018).

The liquefaction disaster criteria, according to SNI 8460: 2017 concerning Geotechnical Design Requirements are generally found when soil material gets cyclic force under the condition of being compressed (undrained) such as an earthquake. During rapid undrained cyclic loading, pore pressures cannot easily escape. As a result, the effective stress decreases to zero, where there is almost no contact between each particle. Because the 
condition of rock formation has not yet occurred compaction (liquefication) in Palu City is still in process (the age of the rocks is still young), which is dominated by alluvial deposits, so that if a shock occurs (earthquake) will occur when the force causes force instability and results in decreased pore pressure, as a result, there is compaction (Janat et al., 2017).
Liquefaction is a disaster that can damage the condition of infrastructure, so knowledge of the potential and vulnerability of liquefaction is very important, especially in spatial planning in the Palu area (BAPPENAS, 2019b).

Based on the results of a study there are 3 categories of potential liquefaction hazards in Palu City (Widyaningrum, 2012) is shown in Figure 5.

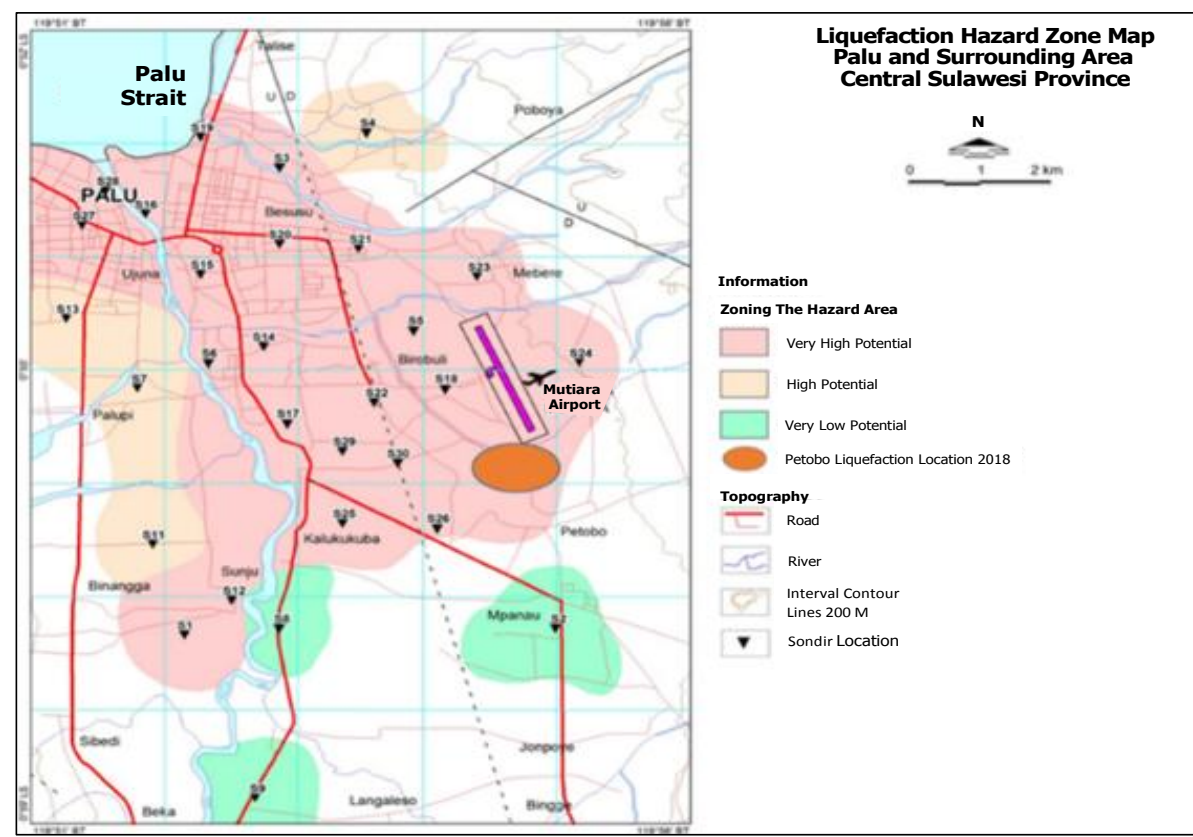

Fig 5. The liquefaction danger zone of Palu City.

On September 28, 2018, a Liquefaction Disaster occurred, especially in Petobo and Balaroa Sub-Districts, where buildings and roads were severely affected. The liquefaction-prone Zone Plan $(K R B)$ is divided into four classification zones:

1. Disaster-Prone Zone 1 covering an area of 3,391.27 hectares spread across all districts.

2. Disaster-Prone Zone 2 covering an area of 1,732.69 hectares and unaffected sub-districts are North Palu District and Tawaeli District.
3. Disaster-Prone Zone 3 covering 671.50 hectares with the same distribution as liquefaction-prone zone 2.

4. Disaster-Prone Zone 4 covering an area of 205.75 hectares spread across the Districts of West Palu, Ulujadi, Tatanga, and South Palu (BPBD, 2018). Palu City disaster-prone zone mapis shown in Figure 6.

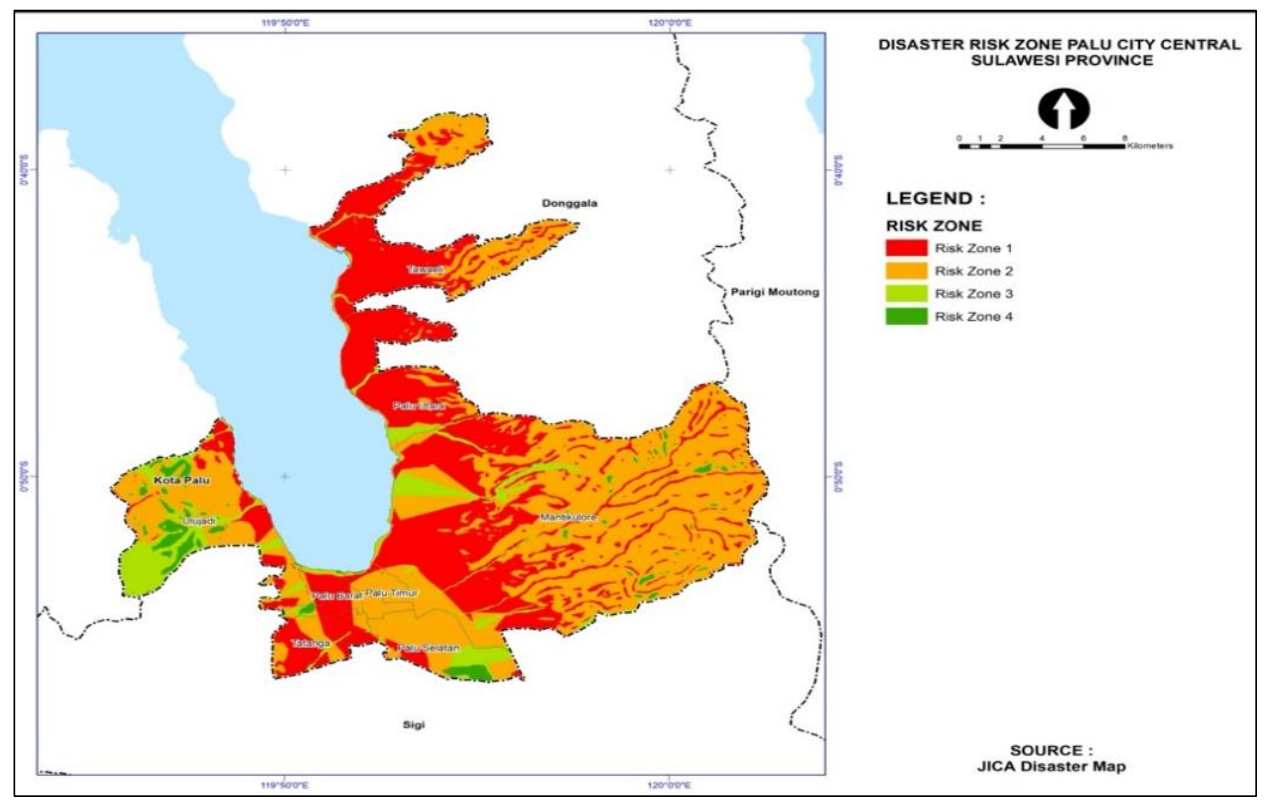

Fig 6. Palu City disaster - prone zone map 
The widespread risk of Palu City liquefaction disaster is shown in Table 1.

Table 1. Widespread risk of Palu City liquefaction disaster

\begin{tabular}{|c|c|c|}
\hline Districts & Risk & $\begin{array}{c}\text { Land Area } \\
(\mathrm{Ha})\end{array}$ \\
\hline \multirow{3}{*}{$\begin{array}{l}\text { Districts. } \\
\text { Mantikulore }\end{array}$} & $\begin{array}{c}\text { Low Liquifaction } \\
\text { Risk }\end{array}$ & 595,50 \\
\hline & $\begin{array}{c}\text { High Liquifaction } \\
\text { Risk }\end{array}$ & 585,26 \\
\hline & No Information & $17.914,30$ \\
\hline Districts. Palu Barat & No Information & 523,26 \\
\hline \multirow{3}{*}{$\begin{array}{l}\text { Districts Palu } \\
\text { Selatan }\end{array}$} & $\begin{array}{c}\text { Low Liquifaction } \\
\text { Risk }\end{array}$ & 30,86 \\
\hline & $\begin{array}{c}\text { High Liquifaction } \\
\text { Risk }\end{array}$ & $1.389,07$ \\
\hline & No Information & 513,41 \\
\hline \multirow{2}{*}{$\begin{array}{l}\text { Districts Palu } \\
\text { Timur }\end{array}$} & $\begin{array}{c}\text { High Liquifaction } \\
\text { Risk }\end{array}$ & 3,33 \\
\hline & No Information & 570,48 \\
\hline \multirow[t]{2}{*}{ Districts Palu Utara } & No Information & $2.928,24$ \\
\hline & $\begin{array}{c}\text { Low Liquifaction } \\
\text { Risk }\end{array}$ & 1,93 \\
\hline \multirow[t]{2}{*}{ Districts Tatanga } & $\begin{array}{c}\text { High Liquifaction } \\
\text { Risk }\end{array}$ & 15,02 \\
\hline & No Information & $1.462,00$ \\
\hline Districts Tawaeli & No Information & $5.924,29$ \\
\hline \multirow{2}{*}{ Districts Ulujadi } & $\begin{array}{c}\text { High Liquifaction } \\
\text { Risk }\end{array}$ & 42,75 \\
\hline & No Information & $6.411,04$ \\
\hline
\end{tabular}

\section{Mitigation of Liquefaction Disaster}

From liquefaction disaster mitigation analyses conducted based on directions from the Palu City spatial pattern and also from the Disaster Prone Areas (KRB) it is expected to be a concrete step to be carried out in liquidation disaster mitigation in Palu City, namely:

1) All land use and building use must comply with the Land Use Zoning Regulations determined by the RTRW and RDTR (BAPPENAS, 2019c).

2) All buildings must follow the Indonesian Building code and related SNI regulations. Non-engineered buildings must follow the main requirements or design prototypes described in PUPR Regulation No. 5/PRT/M/2016. Additional requirements for building structures are explained here for each type of disaster (Kementrian_PUPR, 2016).

3) Each building unit must be equipped with water wells to release excessive groundwater pressure. The requires a well with a diameter of $>1 \mathrm{~m}$ and a depth of $>15 \mathrm{~m}$ (BAPPENAS, 2019b).

4) The building foundation must be a raft foundation (mat slab) with reinforced concrete (RC mat slab structure). Mat Slab must be a single unit and not separate. Even though the foundation uses piles, the building base must still use RC mat slab in anticipation if the piles do not function during the Liquidation one building is not allowed to use several types of foundation designs (pemerintah daerah, 2019b).

5) Engineered buildings must be designed following SNI1726 with additional earthquake priority factors that use the Risk Class one class above for each building (pemerintah daerah, 2019b).

\section{Conclusion and Suggestion}

Considering the risk of liquefaction due to the earthquake and reconstruction efforts in the Palu City area, proper mitigation efforts are very important to reduce the impact of earthquakes in the future.

Base on the explanation before It can be concluded that the ideas of liquidation disaster mitigation for the community have begun to implement although there is still a lot of work to be done in supporting the safety of the community in the face of liquefaction disasters that occur in Palu City.

\section{Acknowledgments}

The first thanks go to Allah SWT for the abundance of grace and pleasure. Next to the two mothers who always pray, and my beloved wife and beloved children and Dr. Mohamad Sapari Dwi Hadian, S.T., M.T. and Dr. Ir. Dicky Muslim, M.Sc., as the supervisor who has given direction and input in this study.

\section{References}

Badan Standarisasi nasional, 2018. SNI 8460-2017 Persyaratan Perancangan Geoteknik.

Balitbang_PUPR, 2018. Kajian Gempa Palu Provinsi Sulawesi Tengah 28 September 2018 (M7.4), Pusat Litbang Perumahan dan Pemukiman, Balitbang PUPR Pusat.

BAPPENAS, 2019a. Proyek Pengembangan Rencana Ketahanan Risiko Bencana Regional di Sulawesi Tengah. Palu.

BAPPENAS, 2019b. Proyek Pengembangan Rencana Ketahanan Risiko Bencana Regional di Sulawesi Tengah.

BAPPENAS, 2019c. Proyek Pengembangan Rencana Ketahanan Risiko Bencana Daerah di Sulawesi Tengah tentang Perencanaan Tata Ruang berdasarkan Pengurangan Risiko Bencana di Sigi. Palu.

BNPB, 2013. KEJADIAN BENCANA INDONESIA AWAL TAHUN 2013, Majalah GEMA BNPB.

BPBD, 2018. Kawasan Rawan Bencana di Kota Palu, Analisis Kebencanaan.

Harun Mallisa, Turu'allo, G., Mallisa, Z., 2009. Mikrozonasi seismic dan analisis respon site specific kota palu. SMARtek 7, 1-9.

Janat, N.R., Wilopo, W., Indrawan, I.G.B., 2017. Kajian Geologi Teknik di Kawasan Pertambangan Emas Poboya, Palu, Sulawesi Tengah, Proceeding, Seminar Nasional Kebumian Ke-10 Peran Ilmu Kebumian dalam Pembangunan Infrastruktur di Indonesia.

Kementrian_PUPR, 2016. Peraturan Menteri Pekerjaan Umum Dan Perumahan Rakyat Republik Indonesia Nomor 05/PRT/M/2016.

Marjiyono, Kusumawardhani, H., Soehaimi, A., 2013. STRUKTUR GEOLOGI BAWAH PERMUKAAN DANGKAL BERDASARKAN INTERPRETASI DATA GEOLISTRIK, Studi Kasus Sesar Palu Koro. J. Geol. dan Sumberd. Miner. 23, 39-46.

Mina, E., Kusuma, R.I., Sudirman, S., 2018. Analisa Potensi Likuifaksi Berdasarkan Data Spt (Studi Kasusproyek Pembangunan Gedung Baru Untirta Sindang Sari ). J. Fondasi 7, 11-21. https://doi.org/10.36055/jft.v7i1.3298

Pakpahan, S., Ngadmanto, D., Masturyono, 2015. Analisis Kegempaan di Zona Sesar Palu Koro, Sulawesi Tengah. Lingkung. dan bencana Geol. 6, 253-264.

pemerintah daerah, 2019a. MATERI TEKNIS RENCANA POLA RUANG.

pemerintah daerah, 2019b. LAMPIRAN MATERI TEKNIS REVISI RTRW KOTA PALU. Palu, pp. 80-92.

pemerintah daerah, 2010. Peraturan Daerah Kota Palu Nomor : 16 Tentang Wilayah Kota Palu. 
Peraturan_Gubernur, 2019. Peraturan Gubernur Sulawesi Tengah Nomor 10 Tahun 2019 Tentang Rencana Rehabilitasi Dan Rekontruksi Pasca Bencana.

Rakhmawan, M.U., Sutaryono, S., Setiowati, S., 2019. Potensi Pengadaan Tanah Berbasis Kebencanaan di Kota Palu. J. Tunas Agrar. 2, 1-18.

Wicaksono, G., 2019. Palu Vertical Settlement, Fakultas Muhamadiyah Surakarta. Surakarta.
Widyaningrum, R., 2012. Penyelidikan geologi teknik potensi liquifaksi daerah Palu, Provinsi Sulawesi Tengah. Kementrian Energi dan Sumber Daya Miner. 43.

(CC) (1) (9) $\begin{aligned} & \text { () } 2020 \text { Journal of Geoscience, Engineering, } \\ & \text { Environment and Technology. All rights reserved. This } \\ & \text { is an open access article distributed under the terms of }\end{aligned}$
the CC BY-SA License (http://creativecommons.org/licenses/by-sa/4.0/). 